\title{
THEMATIC PAPER \\ Reconciliation in Northern Ireland: the value of inter-group contact
}

\author{
Miles Hewstone ${ }^{1}$ and Joanne Hughes ${ }^{2}$
}

Professor of Social Psychology and Fellow of New College, University of Oxford, UK, email miles.hewstone@psy.ox.ac.uk 2Professor of Education, Queen's University Belfast, UK

We gratefully acknowledge Atlantic Philanthropies for unding this research.
Northern Ireland is still riven by segregation, caught between peace and reconciliation. Extensive survey research shows that intergroup contact has a key role to play in achieving reconciliation, whether through generic contact, cross-group friends (most effective) or indirect. Segregation is most profound in education. The new Shared Education Programme (SEP), which provides children with the opportunity to study with and meet pupils from the other community, has demonstrated benefits. The Northern Ireland Assembly's support for SEP is based on sound psychological principles and robust research evidence.

We must never forget those who have died or been injured, and their families. But we can best honour them through a fresh start, in which we firmly dedicate ourselves to the achievement of reconciliation, tolerance, and mutual trust. (Article 2 of the Belfast [Good Friday] Agreement, signed 10 April 1998)

The Belfast Agreement of 1998 marked the beginning of a comparatively peaceful period in Northern Ireland's troubled history after three decades of sectarian violence between groups associated with the main Catholic and Protestant communities. After 1969, over 3600 people were killed in 'The Troubles', and more than half of the population knows someone injured or killed as a direct result of sectarianism. In the 17 years since the signing of the Belfast Agreement, violent conflict has reduced significantly and life in the region has gained a normalcy that could not have been imagined during the worst years of the conflict. However, although the killing has largely ceased, Northern Ireland remains a deeply divided society and nowhere is this more apparent than in education. Northern Ireland still has to move beyond 'peace' (or the absence of war) to 'reconciliation' (when members of previously hostile groups come to mutual acceptance based on trust and respect). Emphasis has long been placed on promoting intergroup contact between Catholics and Protestants. We highlight the importance of this mixing, which has a demonstrable impact on attitudes, trust and even forgiveness. We then focus specifically on mixing in educational settings, which we see as fundamental for reconciliation.

\section{Inter-group contact}

We first explore the evidence in support of the prejudice-reducing effects of direct, face-to-face inter-group contact, and then turn to extended contact (an indirect form of contact). We consider the impact of contact on outgroup attitudes, trust and forgiveness.

\section{Direct contact}

Given that extensive segregation still pervades all aspects of Northern Irish society (Hewstone et al, 2005), positive contact with members of the other community should provide a means of reducing inter-group anxiety (anxiety about mixing with the outgroup), overcoming stereotypes and promoting more positive outgroup attitudes. We have demonstrated this in numerous studies, using both cross-sectional and longitudinal survey designs, with both university students and members of the general public as respondents (e.g. Paolini et al, 2004; Tausch et al, 2010). We have also shown longitudinally, using a large sample of respondents drawn at random from four areas of Belfast, that those who have more cross-group friendships at baseline will be more likely to trust outgroup members 1 year later than will those with fewer or no such friendships (Kenworthy et al, 2015); there was no evidence that those high in initial trust were more likely to seek cross-group friendships.

If generic contact can reduce prejudice, then it is unsurprising that having cross-group friends is particularly effective. Paolini et al (2004) found that having cross-group friends was associated with reduced inter-group anxiety in samples of both students (study 1) and adults in the general population (study 2); contact exerted its effect on attitudes, in part, via reduced anxiety. Kenworthy et al (2015) also showed that cross-group friendship in a large random sample predicted inter-group emotions and trust via more intimate self-disclosure (sharing personal information about oneself).

Our research has also shown that inter-group contact is associated with greater forgiveness, even among respondents from a national sample who had personally been affected by inter-group violence (Voci et al, 2015), and that forgiveness is negatively related to mild psychiatric morbidity (Myers et al, 2009).

\section{Extended contact}

Direct (face-to-face) contact can improve intergroup relations only if people have the opportunity to engage in it. If people do not live in the same neighbourhood, attend the same school, or occupy the same workplace as outgroup members, they are unlikely to come into contact with them, let alone develop friendships with them - hence the value of extended contact, an indirect form of contact that refers to the knowledge that an individual has 
of an ingroup member's direct contact with outgroup members (here, whether a Catholic knows fellow Catholics who have Protestant friends, or vice versa). Paolini et al (2004) asked their participants to report the number of ingroup friends they had who had cross-group friends. Extended cross-group friendship was associated with lower levels of outgroup prejudice (controlling for direct contact), a relationship that was due to a significant reduction in inter-group anxiety.

It might be thought that cross-group friendships will be relatively rare, thus limiting the potential for extended contact. However, Tausch $e t$ al (2011) examined the effects of extended contact via different types of ingroup contacts (neighbours, work colleagues, friends and family members). As expected, extended contact via more intimate ingroup relationships (i.e. friends and family) was more strongly related to outgroup trust than was extended contact via less intimate ingroup relations (i.e. neighbours and work colleagues). But we also found that within each level of intimacy, extended contact was related to outgroup trust only at high levels of rated closeness to ingroup contacts.

Finally, we have found that the negative relationship between extended cross-group friendship and prejudice is consistently stronger for participants with few direct cross-group friends or who live in segregated rather than mixed neighbourhoods (Christ et al, 2010). Christ et al found that extended contact at baseline increased participants' inclination to help outgroup members 1 year later, and this effect of extended contact was amplified for participants who had little experience of direct contact with outgroup members.

\section{Education}

We cannot identify school segregation as a cause of sectarianism, but the mere fact of separate education allows prejudice and stereotypes to flourish. While both communities appear to support this school system, in surveys the majority of the population claim they would support integrated education or would, at least, like to see some mixing between pupils from different schools. How is this best done?

\section{Segregated versus integrated education}

It is estimated that around $94 \%$ of primary and post-primary pupils from the main Catholic and Protestant communities are educated in schools that are predominantly 'own' religion. Dating back to the late 1970 s, and until recently, the only schools-based means of promoting contact has been via integrated schools (of which there are today 62 , across primary and secondary sectors, accounting for around 5\% of overall provision). Research has typically found that integrated education promotes more harmonious relations (Stringer et al, 2009). But do schools have to be specially designed integrated schools to promote reconciliation, or does simply attending a standard state school that has, by chance rather than design, become mixed do some good?
We have begun to answer this question with a 5 -year longitudinal survey of children attending Catholic, Protestant or integrated schools (Hughes et al, 2013). So far, we have reported only on the data from wave 1, based on 51 schools that agreed to take part, and a final sample of 3565 students (2422 Catholics, mean age 12.36 years; 1143 Protestants, mean age 12.34 years). We found, first, that children attending integrated schools generally had more contact and warmer outgroup attitudes than children in Protestant and Catholic schools. In addition, children attending Protestant schools scored higher on measures of contact and attitude than children attending Catholic schools. In exploring possible reasons for these results, we found that the mix of the student body seems to be the most important factor in promoting more positive cross-group relations, rather than the specific type of school attended. Future analyses with additional waves of data will provide a more rigorous analysis of whether attitudes change over time and, if so, how.

\section{Shared education}

Launched in 2007, the Shared Education Programme (SEP) seeks to offer Catholic and Protestant pupils from the different school sectors the opportunity for sustained, curriculum-based contact that can help bring about a more cohesive society (Hughes et al, 2012) (see http://www. schoolsworkingtogether.co.uk).

Rather than emphasising reconciliation objectives, SEP encourages participating schools to devise projects that target other shared educational priorities. In practice, this often means that collaborating schools will agree to offer noncompulsory subject choices at one or other school, and that all children wishing to take these subjects for national exam-based courses will attend the relevant school for classes. As SEP does not require structural change in the school system, it has the advantage of appealing to parents who wish to educate their children within a particular faith tradition, but may also want their children to have some experience of mixing with the other community. SEP offers an alternative for those who are happy for their children to mix with others at school but who also cherish and want to protect a uniquely separate school type.

Within SEP, contact occurs over repeated occasions, across a school year, and provides an experience of direct contact for those involved, and an indirect contact experience for those who themselves do not participate but who have friends who do. Does it work? Hughes et al (2012) reported an initial evaluation of the impact of participation in SEP based on 577 students from 14 schools in Northern Ireland between the ages of 12 and 18 (264 Catholics, 313 Protestants; 162 participants involved in SEP, 415 students not). We measured whether a range of outcomes (outgroup attitudes, positive action tendencies and outgroup trust) were affected via, first, inter-group contact (cross-group friendships) and, second, inter-group anxiety. We 
found that being in a school that is involved in SEP promoted more positive outgroup orientations by increasing outgroup friendships and reducing inter-group anxiety. These results remained significant even after controlling for respondents' religious community, age, gender and whether or not they were involved in other collaborative activities.

\section{Conclusion}

Inter-group contact has a key role to play in promoting reconciliation in Northern Ireland. This contact will be most effective in the form of close friendships with members of the other community, but indirect forms of contact are also effective. Segregation in education will sustain division in society unless interventions such as SEP become widespread, providing each child with the opportunity to meet pupils from the other community. The Northern Ireland Assembly has now passed a motion in support of prioritising shared education (Northern Ireland Executive, 2011). This policy is based on sound psychological principles and robust research evidence.

\section{References}

Christ, O., Hewstone, M., Tausch, N., et al (2010) Direct contact as a moderator of extended contact effects: cross-sectional and longitudinal impact on attitudes and attitude strength. Personality and Social Psychology Bulletin, 36, 1662-1674.

Hewstone, M., Cairns, Voci, A., et al (2005) Intergroup contact in a divided society: challenging segregation in Northern Ireland. In The Social Psychology of Inclusion and Exclusion (eds D. Abrams, J. M. Marques \& M.A. Hogg), pp. 265-292. Psychology Press.
Hughes, J., Lolliot, S. D., Hewstone, M., et al (2012) Sharing classes between separate schools: a mechanism for improving inter-group relations in Northern Ireland? Policy Futures in Education, 10, 528-539.

Hughes, J., Campbell, A., Lolliot, S., et al (2013) Inter-group contact at school and social attitudes: evidence from Northern Ireland. Oxford Review of Education, 39, 761-779.

Kenworthy, J. B., Voci, A., Al Ramiah, A., et al (2015) Building trust in a post-conflict society: an integrative model of intergroup contact and intergroup emotions. Journal of Conflict Resolution (in press).

Myers, E., Hewstone, M. \& Cairns, E. (2009) Impact of conflict on mental health in Northern Ireland: the mediating role of intergroup forgiveness and collective guilt. Political Psychology, 30, 269-290.

Northern Ireland Executive (2011) Draft programme for government (2011-2015). Available at http://www.northernireland. gov.uk/draft-pfg-2011-2015.pdf (accessed 23 January 2012).

Paolini, S., Hewstone, M., Cairns, E., et al (2004) Effects of direct and indirect cross-group friendships on judgments of Catholics and Protestants in Northern Ireland: the mediating role of an anxietyreduction mechanism. Personality and Social Psychology Bulletin, 30, 770-786.

Stringer, M., Irwing, P., Giles, M., et al (2009) Intergroup contact, friendship quality and political attitudes in integrated and segregated schools in Northern Ireland. British Journal of Educational Psychology, 79, 239-257.

Tausch, N., Hewstone, M., Kenworthy, J., et al (2010) Secondary transfer effects of intergroup contact: alternative accounts and underlying processes. Journal of Personality and Social Psychology, 99, 282-302.

Tausch, N., Hewstone, M., Schmid, K., et al (2011) Extended contact effects as a function of closeness of relationship with ingroup contacts. Group Processes and Intergroup Relations, 14 , 239-254.

Voci, A., Hewstone, M., Swart, H., et al (2015) Refining the association between intergroup contact, and intergroup forgiveness in Northern Ireland: type of contact, prior conflict experience, and group identification. Group Processes and Intergroup Relations, published online before print 26 April, doi: $10.1177 / 1368430215577001$.

\title{
MENTAL
} HEALTHLAW PROFILES

\section{Mental health law profiles}

\author{
George Ikkos
}

Consultant Psychiatrist in Liaison Psychiatry, Royal National Orthopaedic Hospital, London, UK, email ikkos@doctors.org.uk
The states of Iran and the United Arab Emirates (UAE), both rich in natural resources, face each other across the Persian Gulf and come closest geographically at the highly strategic straits of Hormuz. Iran enjoys an exceptionally rich historical heritage, as one of the earliest centres of civilisation and political authority in the world and including having been the seat of power of two empires that were the largest in their times. The Abbasid Caliphate in particular reigned strong at the centre during the golden age of Arab science (Al-Khalili, 2012). Today, Iran is an Islamic Republic. UAE is a young federation of seven absolute hereditary monarchies.

As the authors of the two mental health law profiles in this issue report, in both Iran and the UAE recognition of the human rights of people with mental illness remain inadequately defined and protected in law. Gender differences in mental health in the Middle East (Ghuloum, 2013) highlight the need for the law to protect women with suspected or confirmed mental health problems from unfair and harmful approaches to evaluation and management due to patriarchal prejudices. This is something that the dependence on families for decision-making and care may make difficult at times. In Iran, where in addition to civil and criminal courts there are revolutionary and special clerical courts, it must be ensured that patients' rights are protected across the whole range of courts. The fact that the vast majority of the resident population in the UAE are immigrant workers (Zahid, 2014) underscores the need for specific attention to be paid to their needs in mental health legislation as well as service provision. International anxiety is particularly high at present about the health of immigrants in the member states of the Gulf Cooperation Council. 